\title{
비정질 $\mathrm{Ge}_{1}-{ }_{x} \mathrm{Mn}_{\mathbf{x}}$ 박막의 전기적, 자기적 특성에 미치는 열처리 효과 \\ 이병철 · 김동휘 · 찬티난안 · 임영언* · 김도진 · 김효진 \\ 충남대학교 재료공학과, 대전 유성구 궁동 $220,305-764$
}

유상수

삼성테크윈(주), 경남 창원시 성주동 42, 641-120

백귀종

테크노세미켐(주), 충남 공주시 검상동 725-15, 314-240

\section{김창수}

한국표준과학연구원, 대전 유성구 도룡동, 305-600

(2009년 4월 14일 받음, 2009년 5월 20일 최종수정본 받음, 2009년 5월 21일 게재확정)

\begin{abstract}
저온 증착법으로 성장시킨 비정질 $\mathrm{Ge}_{1-x} \mathrm{Mn}_{\mathrm{x}}$ 박막을 열처리하여 전기적, 자기적 특성을 연구하였다. 비정질 박막의 두께는 $1,000 \sim 5,000 \AA$ 이고 비정질 $\mathrm{Ge}_{1-x} \mathrm{Mn}_{x}$ 박막을 고 진공 분위기 하에서 각각 $300{ }^{\circ} \mathrm{C}, 400{ }^{\circ} \mathrm{C}, 500{ }^{\circ} \mathrm{C}, 600{ }^{\circ} \mathrm{C}, 700{ }^{\circ} \mathrm{C}$ 온도에서 3 분 동안 열처리 하였다. 원 시료의 $\mathrm{Ge}_{1-\mathrm{x}} \mathrm{Mn}_{\mathrm{x}}$ 박막을 $\mathrm{X}$-선 회절로 분석해보면 비정질 구조를 보였지만 열처리를 함으로써 결정 화되었다. 비정질 $\mathrm{Ge}_{1-\mathrm{x}} \mathrm{Mn}_{\mathrm{x}}$ 박막에서 결정화가 이루어진 온도는 $\mathrm{Mn}$ 농도에 따라 변화하였다. 비정질 $\mathrm{Ge}_{1-\mathrm{x}} \mathrm{Mn}_{\mathrm{x}}$ 박막은 p형 캐 리어를 가지고 있고 열처리 동안에도 캐리어 형태는 변하지 않았다. 하지만, 전기 비저항은 열처리 온도가 증가함에 따라 증가하 였다. 자기적 특성에서 원 시료의 비정질 $\mathrm{Ge}_{1-x} \mathrm{Mn}_{\mathrm{x}}$ 박막은 강자성특성을 보이면서 큐리온도는 약 $130 \mathrm{~K}$ 정도이다. 열처리한 $\mathrm{Ge}_{1-\mathrm{x}} \mathrm{Mn}_{\mathrm{x}}$ 박막의 큐리온도와 포화 자화값은 열처리 온도에 따라 증가한다. 자화거동과 $\mathrm{X}$-선 분석을 통해 열처리한 $\mathrm{Ge}_{1-\mathrm{x}} \mathrm{Mn}_{\mathrm{x}}$ 박 막에 전기적, 자기적 특성의 변화는 강자성 $\mathrm{Ge}_{3} \mathrm{Mn}_{5}$ 상이 형성되었음을 나타낸다.
\end{abstract}

주제어 : 자성 반도체, 스핀트로닉스 재료, Ge-Mn 금속간 화합물

\section{I. 서 론}

$\mathrm{GaMnAs}$ 을 이용한 성공적인 스핀주입 결과와 같이, 묽은 자성반도체 $(\mathrm{DMS})$ 는 스핀트로닉스 분야에서 스핀 소스나 스 핀 주입에 대한 가능성 때문에 많은 주목을 끌고 있다[1-3]. 최근에는 III-V족 화합물 반도체에 대한 연구 또한 집중[4-6] 되고 있으나, 이러한 재료들은 $\mathrm{Mn}$ 의 용해도가 낮고 큐리온 도가 약 $110 \mathrm{~K}$ 이하인 단점이 있다. 이에 반해 IV 족의 반 도체, 즉 $\mathrm{Si}, \mathrm{Ge}$ 기반의 자성반도체(DMS)[7-13]는 그 특성 이 무척 흥미롭다. 특히 $\mathrm{Ge}$ 은 $\mathrm{Si}$ 이나 $\mathrm{GaAs}$ 보다 훨씬 높은 홀 이동도를 가지고 있는데 이것은 강자성의 상호작용을 조 정하는데 필수적인 요소이며, 이는 $\mathrm{Ge}_{1-\mathrm{x}} \mathrm{Mn}_{\mathrm{x}}$ 계에 대한 최 근 연구동향과 일치하고 자성 반도체가 근본적으로 스핀트로 닉스 재료들로 구성된다는 점을 옹호한다[7]. 또한 1979년부 터 J. J Hauser가 제안한 IV족 비정질 자성 반도체인 SiMn, $\mathrm{XMn}(\mathrm{X}=\mathrm{Ge}, \mathrm{C})$ 처럼 비정질 형태의 재료에 대한 관심[1416]과 최근 비정질 $\mathrm{Ge}_{1-\mathrm{x}} \mathrm{Cr}_{\mathrm{x}}, \mathrm{Si}_{1-\mathrm{x}} \mathrm{Ce}_{\mathrm{x}}$ 과 희토류 원소들이

*Tel: (042) 821-6635, E-mail: yeihm@cnu.ac.kr
도핑된 $\mathrm{Si}$ 에 대한 박막이 연구되고 있다[17-19]. 우리는 비정 질 자성 반도체 $\mathrm{Ge}_{1-\mathrm{x}} \mathrm{Mn}_{\mathrm{x}}$ 박막을 성장시키고 열처리하여 전 기적, 자기적 특성 변화가 스핀트로닉스 소자로 적용 가능성 한지 확인하였다.

\section{II. 실험 방법}

비정질 $\mathrm{Ge}_{1-\mathrm{x}} \mathrm{Mn}_{\mathrm{x}}$ 박막은 $5000 \AA$ 두께의 열 산화막이 형 성된 $\mathrm{Si}(100)$ 면에 열기화 방법으로 증착하였다. 증착 동안에 기판온도는 약 $100^{\circ} \mathrm{C}$, 증착속도는 약 $100 \AA / \mathrm{min}$ 으로 유지하 였다. 이때의 증착압력은 약 $10^{-6}$ Torr이었다. 열처리 진행을 위해 $\mathrm{Ge}_{0.97} \mathrm{Mn}_{0.03}$ 과 $\mathrm{Ge}_{0.84} \mathrm{Mn}_{0.16}$ 의 두 조성의 샘플을 선택 한 후에 비정질 $\mathrm{Ge}_{1-\mathrm{x}} \mathrm{Mn}_{\mathrm{x}}$ 박막을 각각 $300^{\circ} \mathrm{C}, 400^{\circ} \mathrm{C}$, $500{ }^{\circ} \mathrm{C}, 600{ }^{\circ} \mathrm{C}, 700{ }^{\circ} \mathrm{C}$ 온도에서 고진공 $\left(\right.$ 약 $\left.10^{-8} \mathrm{Torr}\right)$ 분위 기 하에서 열처리하였다. 열처리 시간은 각 온도에서 3 분으 로 고정하였다. 구조분석은 X-선 회절장치(XRD)와 투과전자 현미경(TEM)을 이용하였고, 표면조직은 원자력현미경(AFM) 을 이용하여 살펴보았으며, 자기적 특성은 자가특성측정시스 템(MPMS)을 이용하여 5 350 K 온도범위와 함께 다양한 자 
기장 하에서 분석하였다. Hall 효과는 $0.5 \mathrm{~T}$ 의 전자석을 이용 하여 상온에서 측정하였으며, 이때, Hall 효과와 비저항 측정 을 위해 고순도의 인듐을 사용하여 저항접촉으로 측정하였다.

\section{III. 결과 및 토의}

Fig. 1 에서 보여진 것처럼 X-선 회절분석을 통해 원 시료 의 $\mathrm{Ge}_{0.97} \mathrm{Mn}_{0.03}$ 과 $\mathrm{Ge}_{0.84} \mathrm{Mn}_{0.16}$ 박막은 비정질 형태이지만 열 처리 과정에 의해 결정화되었다. 열처리 후에 peak들이 나타 나는 것은 상 분리와 결정화가 발생되었음을 의미한다. 그리 고 비정질 $\mathrm{Ge}_{1-\mathrm{x}} \mathrm{Mn}_{\mathrm{x}}$ 박막의 결정화가 이루어진 온도는 $\mathrm{Mn}$ 농도에 따라 변화하는데, 실험 결과 $\mathrm{Ge}_{0.97} \mathrm{Mn}_{0.03}$ 과 $\mathrm{Ge}_{0.84} \mathrm{Mn}_{0.16}$ 는 각각 $600{ }^{\circ} \mathrm{C}$ 와 $500{ }^{\circ} \mathrm{C}$ 에서 결정화가 이루어졌다. 미확인된 peak들은 복합 2원계 화합물의 형성으로 인해 나타난다. 비 정질과 결정질 모두 Fig. 2에서 보여지는 전자회절패턴은 $\mathrm{Ge}_{1-\mathrm{x}} \mathrm{Mn}_{\mathrm{x}}$ 박막의 열처리 조건에 따라 변화한다. $500{ }^{\circ} \mathrm{C}$ 에서 3 분간 열처리한 비정질 상태의 $\mathrm{Ge}_{0.97} \mathrm{Mn}_{0.03}$ 박막은 Fig. 2(a) 에서 보여지듯이 전자회절패턴에서 널리 퍼지는 고리모양으
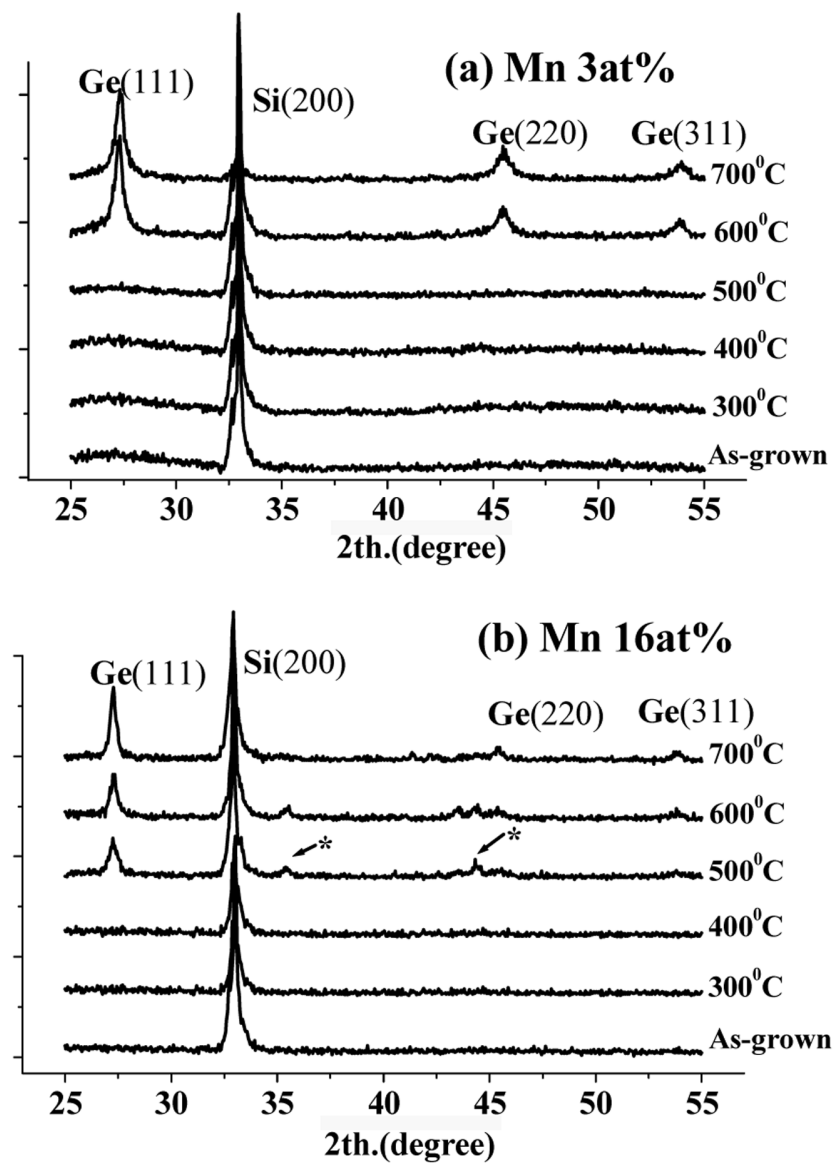

Fig. 1. X-ray diffraction spectra of amorphous $\mathrm{Ge}_{1-\mathrm{x}} \mathrm{Mn}_{\mathrm{x}}(\mathrm{x}=0.03$, 0.16 ) thin films annealed for 3 minutes at various annealing temperatures.
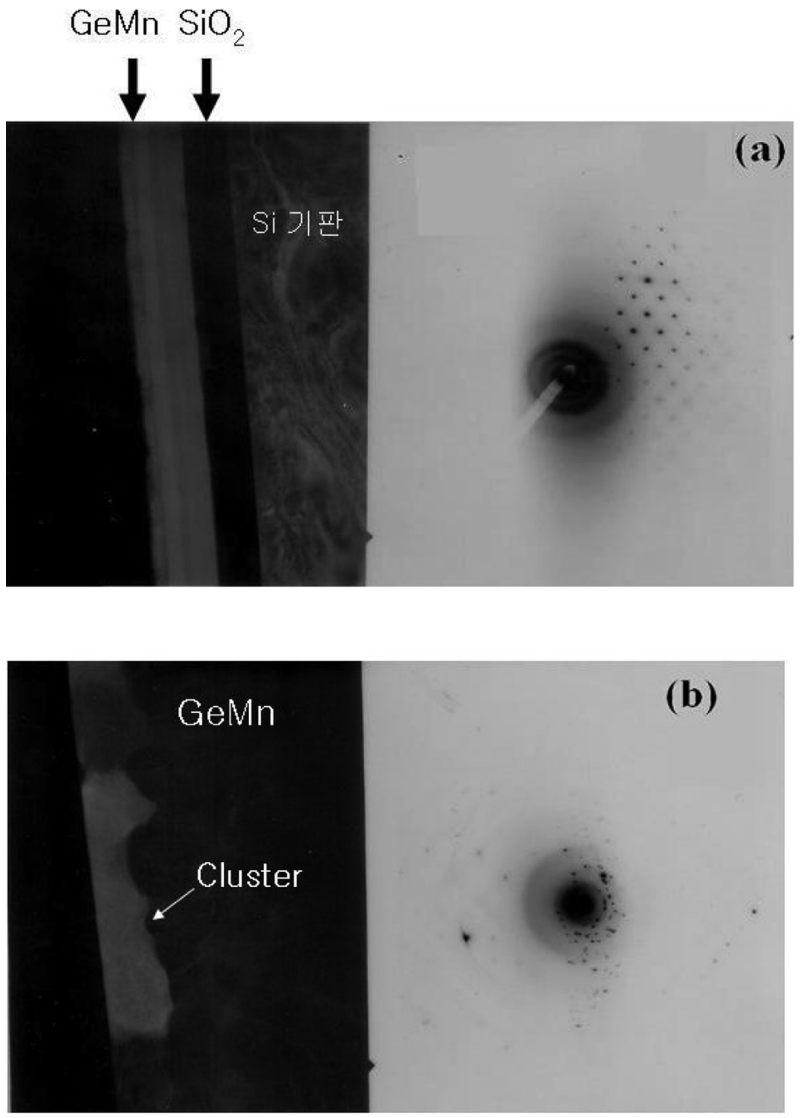

Fig. 2. TEM observation of amorphous $\mathrm{Ge}_{0.97} \mathrm{Mn}_{0.03}$ thin films annealed (a) at $500{ }^{\circ} \mathrm{C}$ and (b) $600{ }^{\circ} \mathrm{C}$.

로 관찰되었다. 반면, Fig. 2(b)에서 보인 것처럼 $600{ }^{\circ} \mathrm{C}$ 에서 3 분간 열처리한 $\mathrm{Ge}_{0.97} \mathrm{Mn}_{0.03}$ 박막의 회절패턴은 널리 퍼지는 고리모양과 또 다른 여러 개의 점들로 나타나고 TEM 이미 지의 밝은 부분을 통해 임의의 결정방향을 갖는 결정상이 형 성되었음을 볼 수 있고 이로 인해 여러 방항을 갖는 결정상 들이 비정질 시료 내에 혼합되어 있음을 알 수 있다. 원자력 현미경(AFM)을 통한 표면 조직 분석 결과, 샘플의 표면은 매우 거칠었고 여러 개의 작은 언덕형태와 그 생김새가 닮았 다. 이러한 형태는 $600{ }^{\circ} \mathrm{C}$ 이상 열처리한 모든 샘플에서 전 형적으로 나타났다. $\mathrm{X}$-선 회절에서 보여지듯이 $600{ }^{\circ} \mathrm{C}$ 이상 열처리한 샘플들은 임의의 결정방향을 갖는 다결정이다. 이에 반해서, 비정질 샘플들은 매우 평평한 표면을 나타내고 전기적 특성은 열처리 온도에 따라 변화하였다. 비정질 $\mathrm{Ge}_{1-\mathrm{x}} \mathrm{Mn}_{\mathrm{x}}$ 박막은 $\mathrm{p}$ 형 캐리어를 가지며 열처리 후에도 캐리어 형태는 변화하지 않았다. 하지만, Fig. 3에서 보여지듯이 전기 비저 항은 열처리 온도에 따라 증가하였다.

이러한 전기 비저항의 변화는 첫째, 비정질에서 결정질로 상변화가 발생하면서 관찰되었다. 전기 비저항은 비정질 구조 내에서 열처리에 따라 미세한 결정상들이 생성하면서 뚜렷하 


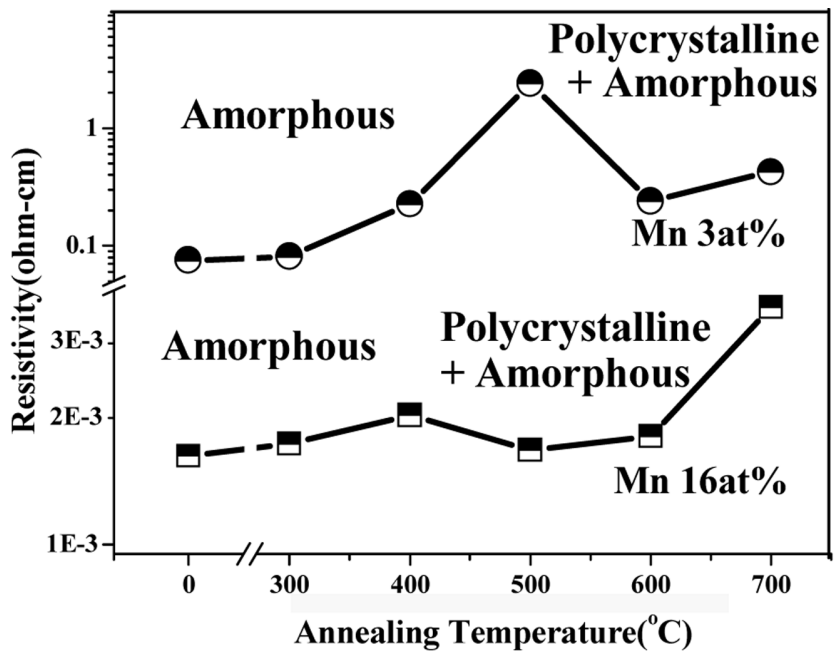

Fig. 3. Resistivity of annealed amorphous $\mathrm{Ge}_{1-\mathrm{x}} \mathrm{Mn}_{\mathrm{x}}$ thin films as a function of annealing temperatures.

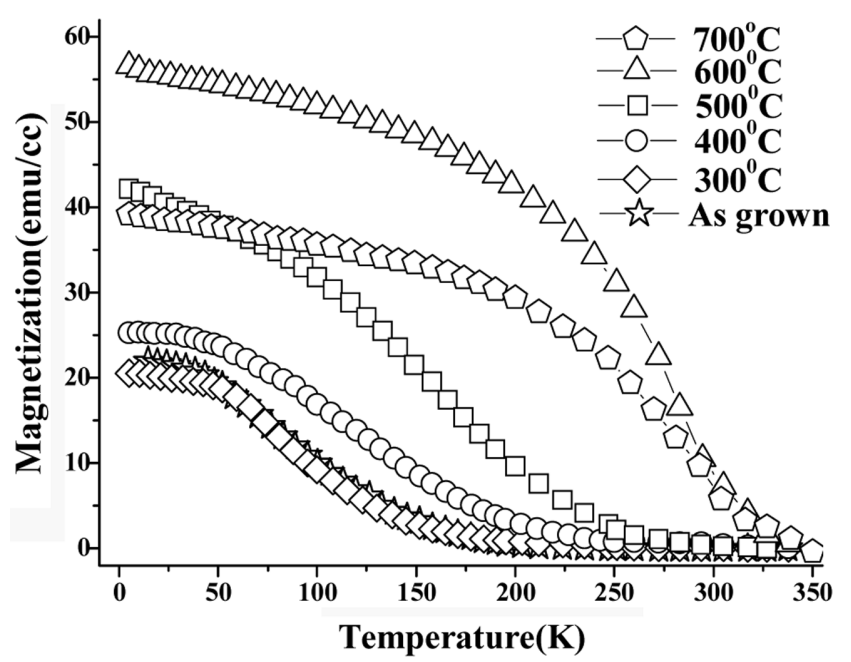

Fig. 4. Temperature dependence of magnetization of amorphous $\mathrm{Ge}_{0.97} \mathrm{Mn}_{0.03}$ thin films annealed at various temperatures. Applied magnetic field was $2 \mathrm{~T}$.

\section{게 감소하였다.}

둘째, 전기 비저항이 비정질 상태에서 열처리 온도에 따라 증가하였는데 이는 열처리 과정 후에 캐리어 밀도가 감소하 였기 때문이다. 원 시료의 비정질 $\mathrm{Ge}_{0.97} \mathrm{Mn}_{0.03}$ 박막의 경우 $3.2 \times 10^{18} / \mathrm{cm}^{3}$ 이였으나 $400{ }^{\circ} \mathrm{C}$ 에서 열처리한 샘플은 $1.2 \times$ $10^{18} / \mathrm{cm}^{3}, 500{ }^{\circ} \mathrm{C}$ 열처리 후에는 $9.7 \times 10^{17} / \mathrm{cm}^{3}$ 로 열처리 온 도가 증가함에 따라 홀 농도는 감소하였다. Hall 효과 측정과 $\mathrm{X}$-선 분석을 통해 미세한 결정상들이 생성될 때 홀 농도는 감소하였고 그것들은 전기 비저항의 감소에 영향을 미친다.

Fig. 4에서 열처리한 $\mathrm{Ge}_{0.97} \mathrm{Mn}_{0.03}$ 박막의 자화에 대한 온도 의존성은 열처리 온도에 따라 다르게 보여진다. 자기장의 방 향은 샘플표면과 평행하게 하였다. 원 시료와 낮은 온도에서

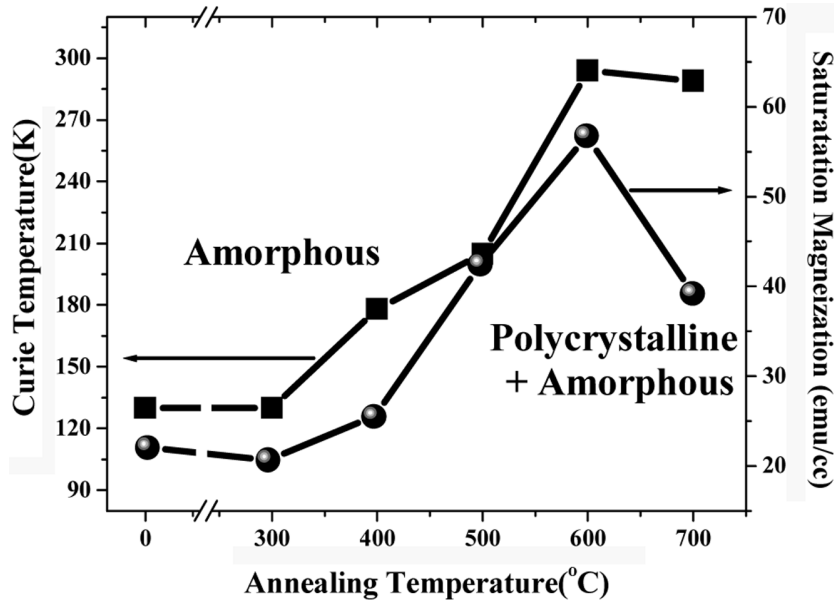

Fig. 5. Change of Curie temperatures and Saturation magnetization at $5 \mathrm{~K}$ of annealed $\mathrm{Ge}_{0.97} \mathrm{Mn}_{0.03}$ thin films as a function of annealing temperatures.

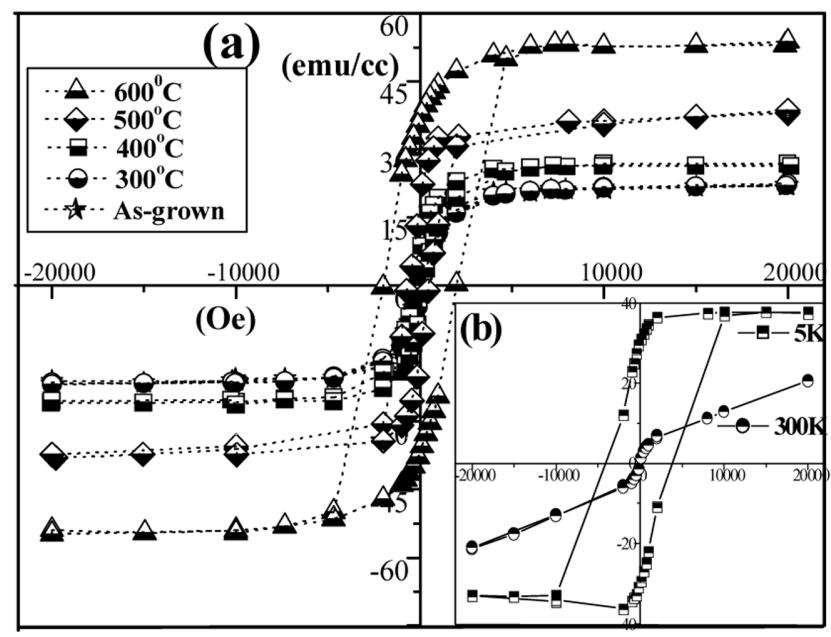

Fig. 6. (a) Magnetic hysteresis loops measured at $5 \mathrm{~K}$ of amorphous $\mathrm{Ge}_{0.97} \mathrm{Mn}_{0.03}$ thin films annealed at various temperatures. (b) Magnetic hysteresis loops at $5 \mathrm{~K}$ and $300 \mathrm{~K}$ of $\mathrm{Ge}_{0.97} \mathrm{Mn}_{0.03}$ thin films annealed at $700{ }^{\circ} \mathrm{C}$.

열처리한 $\mathrm{Ge}_{0.97} \mathrm{Mn}_{0.03}$ 박막의 온도에 대한 자화 곡선은 일반 적인 강자성 자화 곡선과 비슷한 거동을 보인다. Fig. 5에서 보여지듯이 비정질 구조를 유지하는 $\mathrm{Ge}_{1-\mathrm{x}} \mathrm{Mn}_{\mathrm{x}}$ 박막의 큐리 온도는 $130 \mathrm{~K}$ 에서 $205 \mathrm{~K}$ 까지 열처리 온도에 따라 증가하였다. 게다가, 큐리온도는 $400^{\circ} \mathrm{C}$ 에서 열처리한 후에 증가하다가 $600{ }^{\circ} \mathrm{C}$ 부터는 포화되는데 그때의 큐리온도는 약 $300 \mathrm{~K}$ 에 이 른다. Fig. 6는 열처리한 $\mathrm{Ge}_{0.97} \mathrm{Mn}_{0.03}$ 박막의 $5 \mathrm{~K}, 300 \mathrm{~K}$ 에 서의 자기장에 따른 자화 곡선을 보여준다. 뚜렷한 자기이력 곡선은 정렬이 잘된 강자성 구조의 존재를 나타내고 있으며, 온도가 높아지면서 자화값이 감소하는 전형적인 강자성 자화 곡선을 보인다. 더욱이, $600{ }^{\circ} \mathrm{C}$ 와 $700^{\circ} \mathrm{C}$ 에서 열처리한 $\mathrm{Ge}_{0.97} \mathrm{Mn}_{0.03}$ 샘플들은 상온에서도 강자성 특성을 보이고 있다. 
하지만, 앞서 $\mathrm{XRD}$ 결과와 비교하면, 높은 온도 $\left(600^{\circ} \mathrm{C}\right.$, $\left.700{ }^{\circ} \mathrm{C}\right)$ 에서 열처리한 후의 높은 큐리온도 $(300 \mathrm{~K})$ 는 작은 사 이즈의 강자성 $\mathrm{Ge}_{3} \mathrm{Mn}_{5}$ 상의 형성에 의해 나타난다고 판단된 다. 그 이유는 $\mathrm{Ge}-\mathrm{Mn}$ 계에서 오로지 $\mathrm{Ge}_{3} \mathrm{Mn}_{5}$ 상의 큐리온도 가 약 $300 \mathrm{~K}$ 를 가지고 있으며 $[20,21]$, 열처리 온도가 증가함 으로써 자화값이 감소하였기 때문이다 $\left(600{ }^{\circ} \mathrm{C}\right.$ 에서 $56 \mathrm{emu} /$ $\mathrm{cm}^{3}, 700{ }^{\circ} \mathrm{C}$ 에서 $\left.39 \mathrm{emu} / \mathrm{cm}^{3}\right) . \mathrm{Ge}_{3} \mathrm{Mn}_{5}$ 상은 열처리 온도가 증가할수록 $\mathrm{Ge}_{3} \mathrm{Mn}_{5}$ 상과 다른 자화 특성을 갖는 또 다른 $\mathrm{Ge}-\mathrm{Mn}$ 상 $\left(\mathrm{Ge}_{8} \mathrm{Mn}_{11}\right)$ 으로 천이된다. 즉, 열처리 온도에 따라 자 화값이 감소하는 경향을 보인다[22]. 이러한 특정 상의 천이 에 대해서는 이미 알려진 특정 자성상의 거동에 의하여 나타 나지는 자성 특성을 통하여, 특정상의 생성과 천이는 충분히 예측이 가능하다.

우리 경우와 같이, $\mathrm{GaMnAs}$ 에서도 높은 온도에서의 열처 리는 $\mathrm{MnAs}$ 와 $\mathrm{GaAs}$ 로 상분리를 야기시킨다고 보고 되었다 [23]. 이와 대조적으로, 우리는 예상외로 낮은 열처리 온도에 서 보다 높은 큐리온도에 도달하였음을 발견하였고 낮은 열 처리 온도 $\left(400{ }^{\circ} \mathrm{C}, 500{ }^{\circ} \mathrm{C}\right)$ 에서 큐리온도와 자화값이 열처리 온도에 따라 증가하였다. 이러한 경우에는 $\mathrm{Ge}_{0.97} \mathrm{Mn}_{0.03}$ 박막 의 미세구조에 아무런 변화가 없었고 이는 낮은 온도에서 열 처리한 후에 $\mathrm{Ge}_{0.97} \mathrm{Mn}_{0.03}$ 박막은 동질성을 유지하였음을 나 타낸다. 사실, $\mathrm{XRD}$ 와 $\mathrm{TEM}$ 을 통해 우리샘플내에 클러스터가 존재하는지 아닌지를 알기가 어렵다. 분명한 건 많은 반강자 성, 상자성 또는 반자성상들이 $\mathrm{Ge}-\mathrm{Mn}$ 2원계에 존재할 것이 다. 하지만, 우리가 열처리한 비정질 $\mathrm{Ge}_{0.97} \mathrm{Mn}_{0.03}$ 박막으로부 터 얻은 다양한 큐리온도는 Ge-Mn 2원계 내에 이전에 보고 된 상이나 어떤 다른 산화물을 찾을 수가 없다. 따라서 비정 질 $\mathrm{Ge}_{0.97} \mathrm{Mn}_{0.03}$ 박막의 큐리온도와 자화값은 열처리 온도에 의해 다양하게 변화한다고 결론 내릴 수 있다. 하지만, 열처 리 후에 큐리온도와 자화값이 증가하는 것에 대해 조금 더 연구해 볼 필요가 있다. 본 실험에서와 같이 열처리 후, 전기 적으로 홀농도와 이동도가 감소함에 따라 강자성 특성(큐리 온도, 자화값)이 감소하여야 하지만, 본 실험에서는 그 반대 의 결과를 보인다. 열처리에 대해 언급하면, 일반적으로 열처 리는 물질내의 원자위치를 변화시킨다. 예를 들면 합금에서 원자들의 확산으로 인해 원자의 조직(state of order)을 변화 시킨다. 강자성에 대한 열처리 효과를 근거하여 우리는 결과 적으로 열처리로 인해 강자성 특성이 $\mathrm{Ge}_{1-\mathrm{x}} \mathrm{Mn}_{\mathrm{x}}$ 합금의 원자 조직에 의존한다고 말할 수 있다. 또한, 큐리온도는 $\mathrm{Mn}$ 농도 와 홀 농도처럼 평균적인 매개변수를 더하여 $\mathrm{Mn}$ 농도가 증가 함에 따라 같이 증가한다고 알려져 있다. 이 거동은 T. Dietl 등이 제안한 강자성 모델(Zener Model)과 일치한다[24]. 일반 적으로 알려진 자성반도체의 큐리온도에 관한 수식은 다음과 같다.

$$
T_{c}=C X p^{1 / 3},
$$

$X$ 는 치환된 $\mathrm{Mn}^{2+}$ 이온들에 대한 몰분율, $p$ 는 홀 농도이고 $C$ 는 다수 재료에 대한 특정상수이다. 하지만 우리의 경우, 큐 리온도가 고정된 $\mathrm{Mn}$ 농도에서 다양하게 변하고 오히려 열처 리 후 홀 농도는 감소하였다. 이러한 큐리온도의 변화는 $\mathrm{Mn}$ 스핀들 사이의 상호 작용 때문이라고 생각된다. 비록 우리연 구에서 원자배열을 확인할 수 없었지만, 열처리 결과는 강자 성을 야기시키는 캐리어를 알아보기 위해 다소 특별한 원자 배열이 필요하다고 생각된다.

본 논문에서는 열처리 효과에 대한 비정질 $\mathrm{Ge}_{1-\mathrm{x}} \mathrm{Mn}_{\mathrm{x}}$ 박막 의 전기적, 자기적 특성에 대해 연구 하였다. 전기 비저항은 비정질 $\mathrm{Ge}_{1-x} \mathrm{Mn}_{\mathrm{x}}$ 박막에서 열처리 온도에 따라 증가하였는 데 이는 열처리 후에 홀 농도가 감소했기 때문이다. 하지만, 비정질 구조에 예상되는 미세한 결정상들로 인해 전기 비저 항은 급격히 감소한다. 열처리한 비정질 $\mathrm{Ge}_{0.97} \mathrm{Mn}_{0.03}$ 박막은 강자성체이고 포화 자화값은 열처리 온도에 따라 증가하여 최 대 $320 \mathrm{~K}$ 였다. 그로 인해 상온에서도 강자성 특성이 관찰되 었는데 이는 비정질 구조내에서 생성된 작은 사이즈의 강자 성 $\mathrm{Ge}_{3} \mathrm{Mn}_{5}$ 상 때문이다.

\section{감사의 글}

본 연구는 Brain Korea 21 Program(BK21 첨단부품소재 사업단)의 지원을 받아 연구되었습니다.

\section{참고문헌}

[1] Y. Ohno, Nature, 402, 790 (1999).

[2] H. Ohno, Science, 281, 951 (1998).

[3] W. S. Im, et al., J. of Kor. Mag. Soc., 14, 213 (2004).

[4] T. Dietl, H. Ohno, et al., Science, 287, 1019 (2000).

[5] F. C. Yu, et al., J. of Magnetics, 10, 103 (2005).

[6] P. H. Quang, et al., J. of Magnetics, 12, 149 (2007).

[7] Y. D. Park, et al., Science, 295, 651 (2002).

[8] A. Stroppa, et al., Phys. Rev. B, 68, 155203 (2003).

[9] S. Cho, et al., Phys. Rev. B, 66, 033303 (2002).

[10] N. Pinto, et al., J. Mater. Sci.: Mater. Electrons, 14, 337 (2003).

[11] Y. J Zhao, T. Shishidou, and A. J. Freeman, Phys. Rev. Lett., 90, 047204 (2003).

[12] 김우철, 배성환, 김삼진, 김철성, 김광주, 윤정범, 정명화, 한국 자기학회지, 17, 81 (2007).

[13] S. H. Na, et al., J. of Magnetics, 13, 23 (2008).

[14] J. J. Hauser, et al., Phys. Rev. B, 20, 83391 (1979).

[15] J. J. Hauser, et al., Phys. Rev. B, 22, 2554 (1980).

[16] S. S. Yu, et al., J. Magn. Magn. Mater., 304, 167 (2006).

[17] W. B Paek, et al., Phys. Stat. Sol. (b), 7, 1521 (2004).

[18] M. S. Sercheli, et al., Phys. Rev. B, 68, 174418 (2003). 
《연구논문》 비정질 $\mathrm{Ge}_{1}-{ }_{x} \mathrm{Mn}_{\mathrm{x}}$ 박막의 ..... - 이병철 - 김동휘 - 찬티난안 - 임영언 · 김도진 · 김효진 · 유상수 - 백귀종 - 김창수- 93 -

[19] S. S. Yu, et al., J. Magn. Magn. Mater., 304, 170 (2004).

[20] N. Yamada, et al., J. Phys. Soc. Japan., 59, 273 (1990).

[21] Y. E. Ihm, et al., J. Magn. Magn. Mater., 272, Supplement 1, E1539-E1540 (2004).
[22] Y. M. Cho, et al., J. Magn. Magn. Mater., 282, 385 (2004).

[23] J. De Boeck, et al., Appl. Phys. Lett., 68, 2744 (1996).

[24] T. Dietl, et al., Science, 287, 1019 (2000).

\title{
Annealing Effect on Magnetic and Electrical Properties of Amorphous $\mathrm{Ge}_{1-\mathrm{x}} \mathbf{M n}_{\mathbf{x}}$ Thin Films
}

\author{
Byeong Cheol Lee, Dong Hwi Kim, Tran Thi Lan Anh, Young Eon Ihm*, Dojin Kim, and Hyojin Kim \\ Chungnam National University, Daejeon 305-764, Korea \\ Sang Soo Yu \\ Samsung Techwin Co., Ltd, Changwon-city 641-120, Korea
}

Kui Jong Baek

Techno Semichem Co., Ltd, Kongju-city 314-240, Korea

Chang Soo Kim

Korea Research Institute of Standards and Science, Daejeon 305-600, Korea

(Received 14 April 200, Received in final form 20 May 2009, Accepted 21 May 2009)

\begin{abstract}
Amorphous $\mathrm{Ge}_{1-\mathrm{x}} \mathrm{Mn}_{\mathrm{x}}$ semiconductor thin films grown by low temperature vapor deposition were annealed, and their electrical and magnetic properties have been studied. The amorphous thin films were $1,000 \sim 5,000 \AA$ thick. Amorphous $\mathrm{Ge}_{1-\mathrm{x}} \mathrm{Mn}_{\mathrm{x}}$ thin films were annealed at $300{ }^{\circ} \mathrm{C}, 400{ }^{\circ} \mathrm{C}, 500{ }^{\circ} \mathrm{C}, 600{ }^{\circ} \mathrm{C}$ and $700{ }^{\circ} \mathrm{C}$ for 3 minutes in high vacuum chamber. X-ray diffraction analysis reveals that as-grown $\mathrm{Ge}_{1-\mathrm{x}} \mathrm{Mn}_{\mathrm{x}}$ semiconductor thin films are amorphous and are crystallized by annealing. Crystallization temperature of amorphous $\mathrm{Ge}_{1-\mathrm{x}} \mathrm{Mn}_{\mathrm{x}}$ semiconductor thin films varies with $\mathrm{Mn}$ concentration. Amorphous $\mathrm{Ge}_{1-\mathrm{x}} \mathrm{Mn}_{\mathrm{x}}$ thin films have p-type carriers and the carrier type is not changed during annealing, but the electrical resistivity increases with annealing temperature. Magnetization characteristics show that the as-grown amorphous $\mathrm{Ge}_{1-\mathrm{x}} \mathrm{Mn}_{\mathrm{x}}$ thin films are ferromagnetic and the Curie temperatures are around $130 \mathrm{~K}$. Curie temperature and saturation magnetization of annealed $\mathrm{Ge}_{1-\mathrm{x}} \mathrm{Mn}_{\mathrm{x}}$ thin films increase with annealing temperature. Magnetization behavior and X-ray analysis implies that formation of ferromagnetic $\mathrm{Ge}_{3} \mathrm{Mn}_{5}$ phase causes the change of magnetic and electrical properties of annealed $\mathrm{Ge}_{1-\mathrm{x}} \mathrm{Mn}_{\mathrm{x}}$ thin films.

Keywords : magnetic semiconductor, spintronics materials, Ge-Mn intermetallic compounds
\end{abstract}

